\title{
Race, Republicanism, and Domestic Service in the Antebellum United States
}

Mary Cathryn Cain

Current debates in the United States over illegal immigration and domestic labour are predicated on many assumptions, among them the notion that service work is degraded, degrading, and 'unfit' for white Americans. This assumption has roots deep in American history, so deep that it has come to be shared both by defenders of undocumented workers and by their adversaries, and so deep that its origins are rarely considered. Yet from the founding of the republic until the $1830 \mathrm{~s}$, domestic service was regarded in a very different light by white Americans of all social classes. Throughout the Northern states, where slavery had not taken firm hold and was being gradually abolished, domestic service was most commonly performed by young white women who found their work to be valued, respectable and good training for their own eventual marriage and motherhood. Under this so-called system of "helps," a Yankee woman might take in a niece or a neighbour's daughter and teach her the art and science of household management in return for assistance with performing household tasks. This relation resembled that of a master craftsman training an apprentice, with no money being exchanged. The "helps" were regarded not as employees, and not just as members of the household, but often as members of the family itself, sharing living quarters and dining with the others.

This system of helps did not last long into the antebellum period, however. As scholars Faye Dudden and Carol Lasser have shown, the rise of industrialization and the emerging market in immigrant labour created a set of social conditions that drove native-born white American women from service and replaced the system of helps with a wage relationship. Dudden and Lasser have explored the impact of this new economy on American serving women, explaining that it opened the door both to more autonomy for and greater exploitation of servants. ${ }^{1}$ But servants were not the only women whose conditions and identities were affected by the transition from "helps" to service: the women who employed them were also forced to contend with changes to the material circumstances of their households, as well as with a host of new ideological problems. These problems stemmed from the intrusion of the market economy into the domestic space, compounded by the fears associated with bringing strange hirelings into the home and trusting them with intimate family tasks. Together these developments threatened the sanctity of the home and thrust the household mistress into the traditionally unfeminine-and therefore, in the nineteenth century, uncomfortable-role of acting as a boss to dependent labour. The fact that her employees were most 
often Irish immigrants or African Americans created another level of anxiety for the white employer. Overlaying these concerns was the Northern, middle-class white women's very real fear that they were compromising their political identities by relying on hired servants who now worked for them rather than with them as the helps had. Prescriptive writer William Alcott wrote in 1837 that the evolution of service into a wage relation was producing "a feeling which is contrary to true republicanism as light is to darkness." Likewise, popular author Lydia Maria Child cautioned that a system of paid domestic labour was "a bad one under any form of government; but in our country, its application is peculiarly preposterous." 3

Despite these grave concerns about wading into the new market for domestic labour, most Northern, urban, middle-class white women found they had little recourse. For one thing, these women were unwilling to take on all of their domestic chores themselves, especially those tasks that were "rough, or dirty, or slavish." ${ }^{4}$ One household mistress summed up her dependence on hired labour in 1837: "That 'servants are great plagues' may be the fact; but I am, nevertheless, bold enough to assert that it is a greater plague to be without them." ${ }^{5}$ For other employing women, the question of hiring a servant revolved less around convenience than status. The author of one household manual explained to her readers that, "humble as was our position in the great world, we had a certain status to maintain. We must live in a respectable house, we must dress genteelly at least, and keep a servant, too." Whether for the practical labour servants supplied or the status they conferred, the large numbers of servants continually employed throughout the antebellum North suggest that middle-class white women saw them as essential to their standard of living. Simply doing without domestic labour seems not to have been a viable option for most middle-class household mistresses. As a result, the primary challenge that middle-class white women faced after the decline of the system of helps was not how to resist the new relations of service, but how to reconcile those relations with their understanding of traditional gender roles and political responsibilities. In other words, how could the household mistress open her home to the forces of commercialism, engage "others" to perform crucial tasks in the intimate domestic space, and position herself in the unaccustomed role of employing boss, while at the same time protecting her home, upholding republican values and maintaining her own womanliness? I argue that white household mistresses most effectively answered this challenge by racializing the relations of service.

This essay examines relationships between mistresses and servants in the antebellum US North, demonstrating that domestic employers increasingly viewed their servants through a prism of race, so as to protect their own ideological interests. I take seriously the rhetoric of republicanism that infused their public meditations on the evolution of household service, and I am mindful of the fact that the republic these women revered was a slave republic. Though not slaveholders themselves, the women I study were fully attuned to the relations of chattel slav- 
ery, and even as they distanced themselves from most of the particular abuses and exploitations of the institution, they appropriated its racial logic. ${ }^{7}$ This logic promoted a racialized division of labour, positing white people (especially middle-class white people, with their bourgeois standards and economic independence) as most appropriate in supervisory roles, while indicating that people who were not white-like African Americans and the Irish-were better suited to the dirty, dependent work of the household.

Other studies have tracked the conditions faced by Irish and African American women in service in the antebellum North. These groups of women have warranted much scholarly attention because they clearly made up the vast majority of domestic workers in this context. ${ }^{8}$ But because I am interested in the ideological implications of the racialization of service, I train my focus on two smaller but more ideologically fraught cohorts of service workers: black men and native-born white women. Their treatment by white female employers offers telling insight into how mistresses constructed notions of race within the household and how they used those notions to mediate their own positions of authority. Ultimately, this study makes two main contributions to our understanding of race and domestic service in America: first, it suggests part of why and how the employers' racialization of the relations of service led to the lasting stigmatization of paid household labour; secondly, it uncovers the primary context in which middle-class white women constructed and deployed their own white identities. The fact that white mistresses were assuming leadership over servants who were, notionally, non-white meant that the new relations of service did not have to be threatening, commercial, unrepublican or unwomanly; instead, by reinforcing what nineteenth-century white Americans saw as a "natural" hierarchy of race, the antebellum mistress-maid relation could, in fact, serve to protect the ideological interests of middle-class white womanhood.

A spate of recent historiography has examined the construction of whiteness in nineteenth-century America. Notable works by David Roediger, Noel Ignatiev, and Matthew Frye Jacobson, among others, have traced the efforts of otherwise-marginalized European-Americans to harness the compensatory power of whiteness for political gain. In doing so, these studies have taught us much about the previously unseen, unspoken ways in which white privilege has operated in American history. ' However, a striking feature of this literature is that it pays almost exclusive attention to the experiences of working-class men and their struggles for political viability. My work demonstrates that like white workingmen, middle-class white women relied on the construction of a white identity to resolve fundamental problems of political self-definition in the slave republic. But their brand of female whiteness was, I contend, class-specific and gender-specific. Rather than granting them entry into the arena of public politics, it permitted them to inhabit the female sphere more comfortably and without having to relinquish their republican sensibilities. One key facet of female whiteness as it was con- 
structed in the antebellum period is that it enabled middle-class white women to assert authority over hirelings without compromising either their true womanliness or their republican virtue. This was no mean development, as leadership in the private realm shaped women's lives as much as men's were shaped by participation in the public. In her influential monograph Home and Work, Jeanne Boydston explores the redefinition of household labour in the antebellum period and its ramifications for the status of middle-class American women. Describing what she terms the "pastoralization of housework", Boydston explains that changes spawned by industrialization and commercialism in the early nineteenth century led to the perception that middle-class housewives should be "the embodiment of all that was contrary to the values and behaviors of men in the marketplace." Boydston argues that this gendering of economic behavior led to the re-evaluation of housework as something other than productive labour, which accordingly "made [women's] status as producers in the economy suspect." 10 But in this republic, access to productivity determined more than one's economic status; it was also a measure of political identity, for no one could lay claim to the entitlements of republicanism without also contributing to the common good. Consequently, middle-class women who employed domestics felt their republican identities threatened in two senses: first, they feared that by delegating household labour to other women, they were in fact promoting their own idleness and failing to prove their own virtue. Additionally, many mistresses had misgivings about a labour system that engendered the two-way dependence of servants on mistresses and mistresses on servants.

The anxiety that middle-class white mistresses felt over appearing unrepublican is perhaps most evident in the many justifications and euphemisms they concocted to describe their relationships to their servants. Various circumlocutions for the term "servant", such as "president of the dishcloth," and "my woman in the kitchen", entered the vernacular in this period, as white female employers sought to soften the significance of their own roles as employers of dependent labour. ${ }^{11}$ In the 1835 novel Home, Catharine Maria Sedgwick enigmatically referred to domestics as "republican independent dependents," so as to disguise the subordinate, politically-underprivileged status to which servants were relegated within the household. ${ }^{12}$ Sedgwick sounded this theme once more in the preface to Live and Let Live, maintaining that the "women of this country of every grade are independent, self-directing beings." As if to mollify the republican critics of domestic service, she reminded her readers that "the employers have certain untransferable duties and the employed certain unquestionable rights," which were intended to forestall any breach of republican relations. ${ }^{13}$ A year later, Eliza Follen portrayed a fictional housewife who defended the hiring of servants by explaining, "you know, my husband and I are republicans, even radicals, as I suppose you would call us, and desire the abolition of all disgraceful servitude, and therefore encourage the spirit of independence in our domestics."14 Although Follen's other char- 
acters are unsure what to make of this assertion, the author is clearly attempting to articulate a domestic philosophy that would allow middle-class white women to retain their servants, while avoiding the unwelcome political implications that the relations of service entailed.

In the end, the attempts of Sedgwick, Follen, and others to render the relations of domestic service in acceptably republican terms proved untenable. After the decline of the system of helps, there seemed to be no appropriate way that middle-class white mistresses could maintain the pretense of republican virtue while bringing foreign-born domestics into their homes to perform the most menial of household tasks. By 1845, a sticky web of social, economic and political forces had combined to make the reconciliation of republican ideology and traditional domestic service all but impossible. First, Yankee women had been replaced by Irish labour. Secondly, hirelings replaced helps. Third, drudgery replaced companionate labour. As a result of these factors, the position of the servant in the household emerged as something clearly distinct from-and subordinate to- that of the employing family. Unlike their British counterparts, white American women could not simply rationalize the employment of degraded servants as a function of class differentiation within an aristocratic regime. Instead, in order to come to grips with these several difficult transformations, middle-class white women reached for a new category of analysis that could reorder their domestic relationships in easily-recognizable and politically-sensible terms: they began to perceive service as a function of race. While the British model of service was rejected for being clearly unrepublican, the middle-class white woman had another, more immediate, more useful and less politically problematic heritage on which to draw: she remained heir to a New World tradition of racial exploitation - a tradition that had historically complemented the prevailing American ideas of republicanism. By recasting the mistress-maid dynamic in terms of race difference, white women could claim that their hiring practices affirmed rather than threatened American belief in the virtues of a free, white citizenry. And as a very important corollary, these women could also continue to enjoy the social and material advantages that derived from employing others to do their dirty work.

The swelling ranks of Irish women in domestic service, coupled with the considerable numbers of free black women who performed such labour meant that it required no great political nor ideological leap for antebellum white American mistresses to imagine their servants, in Harriet Spofford's phrase, "as different a race from ourselves as though they were chimpanzees."15 Spofford's ugly analogy illustrates the fact that domestic service in the antebellum North was getting blackened in two separate but related senses. First, as native-born white women unequivocally rejected service jobs, non-white women were ready to take their places, so in terms of racial composition, the domestic workforce was getting blacker. However, the shift in the household labour from white helps to black servants did not, in itself, account for the blackening of such employment. The den- 
igration of household service had a more important ideological component as well: not only was service becoming work that white people did not do, but it was increasingly considered by whites to be appropriate only for non-whites. Fanny Fern's 1855 novel Ruth Hall traces the travails of its title character, a middle-class white woman who is suddenly widowed and must dismiss her servants in order to make ends meet. Ruth's associates are unsupportive of this decision, and warn her that she cannot perform all of the household labour herself, for "you are as white as a sheet of paper."16 Instead, middle-class white Americans believed that Irish and African American women were particularly suited for the work of service, as they seemed to descend from political traditions that engendered dependency. Writing about the Irish in 1837, Catharine Maria Sedgwick claimed that "the abuses of government have left them ignorant, degraded them, and deprived them of their birthrights as members of the human family." As "ignorant", "degraded", and virtually sub-human, Irish women appeared, in the white mind, to be naturally inclined to serve.

Such justifications for the natural serving status of the Irish conformed to white women's understanding of the condition of African American slaves. In a treatise on "the African in America ... to find is true position and place him in it," nineteenth-century reformer Emma Willard offered a strongly-worded analysis of the "natural" racial order and of prescribed social and economic roles for black people. She explained to her readers that the reason "why the Almighty has seen fit to distinguish them [blacks] by colour, is that their place in the family shall be unmistakably settled, so that all jealous heartburnings and vain expectations shall be spared, and a permanent order in the household be established." "18 Even the more progressive Lydia Maria Child suggested that African Americans were somewhat deserving of their inferior status and servile fate. Despite her objection to "the detestable theory that God made one-half his children to be slaves to the other half," Child noted that black slaves failed to take an active hand in winning their own emancipation —as, she implies, white people would. Ultimately she accounts for this failure in racial terms, claiming that "the negroes" were "too docile" to sustain "republican hopes". In order to be republican, in this analysis, one could not be servile, docile or black. Elsewhere in the same discussion, Child compared the political sensibilities of African Americans to the Irish, noting that they were each "a people trampled on for generations and therefore ignorant and violent," making them unfit for equal status in the republic. ${ }^{19}$

The racialization of domestic service in America took place within a context of fervent white republicanism. But it also took place within a society that condoned race-based chattel slavery. In the antebellum period, the ready comparison of domestic service to black slavery caused the former to be racialized. Its negative connotations were thereby made superlative. The lack of freedom afforded to domestics in this era, the deference the job required, and the practice of "boarding in" under the employer's roof_-and watchful eye-were conspicuous- 
ly reminiscent of the conditions of slavery, particularly in the wake of paternalist defenses of "the peculiar institution." Apologists for slavery, like James Henry Hammond and George Fitzhugh, explained that black people constituted a natural underclass who, because of their limited intellect and ability, were necessarily dependent on their masters. Blacks were designed by nature, the argument went, "to do the menial duties, to perform the drudgery of life." 20 Not all Americans agreed, of course, with this rationale as justification for race-based slavery. However, the redefinition of serving work (and Southerners routinely referred to their slaves as "servants") as appropriately black corresponded to Northerners' advancing perception that service was an unrepublican occupation. According to David Roediger, the US was becoming "a society in which Blackness and servility were ... thoroughly intertwined-North and South." ${ }^{21}$ The nineteenth-century writer Harriet Spofford observed the particular nature of domestic service in America, noting that "here it has been seen in juxtaposition with actual slavery," which was problematic "because more here than elsewhere the worth of the individual is counted." ${ }^{22}$ Slaves, accorded no worth as individuals, were unable to establish any claim within republican ideology, which set an unenviable precedent for freely hired servants. In the decades after 1820, as a result of republican anxiety fueled by racist ideology, domestic servants in the North were painted with the same brush as Southern slaves. Lucy Maynard Salmon, the author of the first academic study of domestic service in America argued as early as 1901 that antebellum American white women were unwilling to enter jobs that had been denigrated by their correlation to slavery and by the "almost exclusive employment of foreigners in domestic service." ${ }_{23}$ By mid-century, the mere willingness of a worker to enter service-even if compensated with wages and board-ran counter to the principles and expectations of republicanism, and therefore, cast aspersions upon that worker's racial identity.

Christie Devon, the protagonist of Louisa May Alcott's semi-autobiographical novel Work, A Story of Experience, learned this lesson first-hand. The plot of the novel traces its young, Yankee heroine through various employments, as she endeavors to secure financial independence from the aunt who had raised her. Christie first accepts a position as a domestic, which she did not yet view as demeaning work for a white woman: "I never thought it a degradation to do it [housework] for Aunt Betsey, so why should I mind doing it for others if they pay for it?" she mused optimistically on her first day of service. Christie's optimism was perhaps fueled by her initial perception that there was still a demand for white "American" servants, who would be respected for their reliability and treated like the old-style helps, which were only just then being phased out. She was thus ready to take "her place among the ranks of buxom German, incapable Irish and 'smart' American women; for in those days foreign help had not yet driven farmers' daughters (i.e., Yankee women) out of the field, and made domestic comfort a lost art." Christie soon learns that her expectations had been naive, however, 
that the relations of service were irrevocably changing, and that no white woman could remain in service for long without feeling her character and her independence besmirched. After a very short stint Christie leaves service, "vowing not to be a slave to anyone" anymore. ${ }^{24}$

The relations of domestic service portrayed by Louisa May Alcott—and lived by hundreds of thousands of non-fictional women in the antebellum USdevolved from political and cultural forces that were distinctively American. As a result, the experience of service in the US was distinctive as well. Thanks to the nation's dual traditions of republicanism and slavery, service was defined not only as a non-white occupation, but also as non-male. Unlike in Europe where as many men as women entered service (and where servants often reproduced, so that sons followed in their fathers' footsteps as butlers and valets), white American men unequivocally rejected domestic work. Though white men occasionally took positions as gardeners and grooms in the US, they were careful to avoid jobs that required them to serve physically under a master's roof, and virtually none of these gardeners and grooms consented to "live in". The requirements of republican independence made it impossible politically, socially and psychologically for white male citizens to perform the blackened labour of domestic service.

Furthermore, the uncomfortable parallel to slavery made service an unwelcome option for free black men in the urban North. Among former slaves especially, like Frederick Douglass, the prospect of working for a new master was unthinkable, even for wages. Douglass was pleased, instead, to report that his first job in freedom was "stowing a sloop with a load of oil. It was new, dirty, and hard work for me; but I went at it with a glad heart and a willing hand." The reason for Douglass's pride: "I was now my own master." 25

Despite the generally disparaging nature of household work, a small segment of the black male population of the urban North did find it to be respectable and financially rewarding employment-employment that did not always entail deference to a master. These men were "public waiters" who rented out their services for special occasions, fueling an antebellum fashion; according to a character in Sarah Josepha Hale's 1845 novel Keeping House and Housekeeping, it was "just the thing to get a coloured man," to work at dinner parties, for the presence of black male servants gave "quite an air of gentility to the establishment." 26 In 1859 Eliza Leslie advised her middle-class white female readers that "[i]n preparing for a party it is well to send for one of the best public waiters, and consult with him on the newest style of 'doing these things.' A respectable colored man will be found the most efficient for this purpose." ${ }^{27}$ When Margaret Bayard Smith hosted a dinner party in Washington, DC to welcome Harriet Martineau, she hired the distinguished public waiter Henry Orr to manage the affair. Orr was given free reign to design the menu and to oversee Smith's live-in "girls." Afterwards, Smith recommended him as "the most experienced and fashionable waiter ... He is almost white, his manners gentle, serious and respectful, to an uncommon degree and his 
whole appearance quite gentlemanly." ${ }^{28}$ Gentlemanly, she meant, for a black person.

The emergence of the black waiter as a status symbol in Northern white antebellum households - even if the waiter was only a temporary member of the household staff-derived, in part, from the rarity of male servants in the US in this period. Thus, at a material level, the very image of a distinguished male waiter was a conspicuous display of the host's resources. The fact that these male servants were black, however, was no coincidence; for even if the healthy wages commanded by public waiters had been enough to entice white American men into the profession, it is not at all clear that they would have been hired by white women. Middle-class hostesses were firm in their insistence that "coloured men" made the best waiters, perhaps because the cultural and psychological association between servility and negritude was so completely accepted. In the republican climate of antebellum America, a white male servant would have been considered by hostess and guest to be a political implausibility. Moreover, the "gentility" that black waiters supposedly bestowed on the hiring household hinged on the racial difference between servant and served. After all, a black man in uniform who answered the door and waited at the table reminded white party guests - if not the waiter himself-of the Southern house slave, invoking an air of the wealth and gentility of the plantation. (This was, in fact, a relatively safe fantasy for Northern whites, even as public sentiment started to turn against slavery and its political implications. In the context of the bourgeois urban dinner party, when it was understood by all attending that the help had been hired freely and paid handsomely, representations of Southern slave labour served essentially to confirm the class position of the host and hostess, without conjuring up the image of slavery's human costs.)

For the waiters, themselves, such contract work was rendered far less objectionable than regular service, because in no small sense, they could be their own masters. They worked only by agreement and only for short-term commitments, meaning that they could leave unwelcome positions without significant fear of reprisal or repercussion. Because they were in such great demand, they could command premium wages and respect-both of which their employers gratefully paid. In her best-selling etiquette book, Eliza Leslie instructed her readers that black waiters, even if youthful, "were too genteel to answer to the name of boys" and should not be addressed as such. ${ }^{29}$ Ironically, black men outside the serving profession were never afforded this courtesy.

In point of fact, it cost the middle-class white woman little to treat the black waiter with this modicum of respect, for their relations were still underpinned by a logic of race. This logic ensured that ultimate authority rested with her, and that authority was made culturally and ideologically potent through the popular understanding of racial differences between servant and served. The racialization of service in the urban, antebellum North placed the white middleclass woman at the head of a household staff (admittedly, it was often a staff of 
just one, the "maid-of-all-work") that was subordinate, unrepublican and nonwhite. It is important to understand that the white mistress' construction of racial difference between herself and her employees was not an attempt to reinforce her position of power over the servant; rather, she sought the means both to justify and to mediate her superior position. After all, the white woman's primary problem was not maintaining authority within the household, but construing her authority in ways that accorded with dominant political, class and gender ideologies. In constructing a white racial identity for themselves, white women provided themselves with the means and the justification for wielding considerable power within the domestic sphere, while simultaneously upholding both the spirit of American republicanism and of "true womanhood". As long as the servants she managed occupied a blackened status, there was nothing improper, unrepublican or unwomanly in her role as the "household boss." ${ }^{30}$ Because she gave orders to non-white servants, whether hired temporarily like public waiters, or domestics who lived in, the white woman avoided the presumption that their domestic relations were aristocratic: they simply accorded with the prevailing racial ideology of the day. Republican ideology made no room for aristocratic distinctions based on the rank of class. Racial distinctions, however, had long been embedded in America's political economy and therefore supplied a hierarchical model that was both useful and, for them, defensible. ${ }^{31}$

And such race-based relations were not unwomanly, because it was no inordinate presumption of authority for white women to place themselves in a position of superiority over a member of the dependent black underclass. Indeed, Emma Willard specifically argued that the employment of non-white servants enabled white women to fulfill their gender roles more completely. Given that "the servant's place in the family is sanctioned by God," Willard pondered, "who knows that in forming the negro He has not had it in view to create a race with a mission to serve the white women and add strength to their physical weakness." ${ }^{32}$ Thus, we see that in order to resolve problems of class and gender politics within the household, white women deployed their new white racial identities to enormous effect.

Perhaps the most compelling evidence of the racialization of the antebellum Northern, urban, middle-class household is found, ironically, in the relationship between the few Yankee maids remaining in service and their mistresses. Though uncommon, the relationship illuminates the extent to which the dynamic of service had changed in the years following the decline of "helps" and lays bare the heightened political stakes of white women's white identity and the way it operated within the confines of domesticity. In the 1880 s journalist Helen Campbell prepared the first professional study of white female workers who had left service to take factory jobs. Campbell interviewed a number of these women to determine their reasons for rejecting household labour, and the women's responses are instructive: they claimed resoundingly that domestic service was 
objectionable work because it threatened an individual's independence. "It's freedom that we want when the day's work is done," reported Margaret M., a 23-yearold "American" woman. As a servant, she said, "you're never sure that your soul's your own, except when you are out of the house, and I couldn't stand that a day." ${ }^{33}$ A cotton-mill worker told Campbell: "It's hard to give up your whole life to somebody else's orders, and always feel as if you was looked at over a wall like." ${ }^{34}$ The words of these former domestics suggest that the stigma attached to serving derived essentially from its increasing incompatibility with republican values, which stemmed, in turn, from the evolving nature of the mistress-maid relation. Antebellum white women understood service in a very different context than their mothers had. Previous generations of Americans had considered the experience of "helping" in another's home to be normal and healthy preparation for a woman, especially one on the verge of marrying and establishing her own household. In that climate, service had done nothing to jeopardize a woman's republican virtue; on the contrary, it proved her usefulness and resourcefulness and provided the domestic training which formed the foundation of "republican motherhood". By comparison, the women who entered the more anonymous, exploitative brand of service that replaced the system of "helps" in the 1830s and 1840s seemed anything but virtuous. No longer a reciprocal relation, domestic service was devalued and as a class, servants were now despised.

Catharine Maria Sedgwick also investigated the problem of reconciling service with republicanism, but she did it within a fictional context. Her novel depicts Yankee help as a vanishing breed. It traces the experiences of Lucy Lee, the daughter of an impoverished, native-born, white attorney, who must enter service in order to support her family. The pressure to earn wages as a servant is both alien and discomfiting to Lucy, and she resolves, "I shall try to make them [her employers] love me a little-it would be hard indeed to work for nothing but money." ${ }^{35}$ In other words, this Yankee daughter could not imagine herself in the mold of an Irish domestic, a servile wage worker, a mere hireling. David Roediger has demonstrated that in the antebellum period, "hirelings and slaves were sometimes connected in popular logic," for both posed "a threat to republican liberty." ${ }^{36}$ Lucy Lee and the other native-born white characters of Sedgwick's novel are keenly aware of the danger described by Roediger and struggle throughout the story to stave it off. The night before Lucy is to assume a position in the Broadson household, her mother reminds her that "though we live in a republican country, the truth is, we have inequal conditions." The best that Mrs. Lee can do to protect her daughter's republican identity within the context of service is to advise Lucy: "I do not wish you to be servile-I would not have you imitate the manners of foreign servants. ${ }^{37}$ The challenge then for Lucy was how to perform blackened labour without being blackened herself.

While a white middle-class mistress had grave apprehensions about hiring her domestic servants from a public labour pool, the task of hiring was made 
far easier on the rare occasions when Yankee women applied for an advertised position. "It is natural I should prefer an American girl," stated one hiring mistress, explaining her employment of a Yankee stranger, despite having promised that job to the Irish-born cousin of her upstairs maid. ${ }^{38}$ Even when unknown to a new mistress, native-born white American women were usually assumed to be wholesome and reliable, and their reputation for hard work was widely recognized both at home and abroad. "An English woman, a competent judge," according to Catharine Maria Sedgwick, claimed "that the very best domestics she had ever seen ... were the American female domestics." ${ }^{39}$ But these American girls were valued for much more than their industriousness; their familiar ethnic backgrounds were also an asset, as middle-class employers could feel safe that Yankee servants would bring no dangerous or foreign influences into their homes. This reassurance was especially important for the middle-class mothers of young children. "Beware of trusting an infant, too confidingly to an European Nurse," warned Eliza Leslie, because "no good ever accrues from it." She related horror stories of American children learning to speak with Irish brogues or, worse, of Irish maids taking their employers' children for walks in "dirty alleys ... and the child has in consequence taken a disgusting disease." Perhaps the greatest concern of middle-class parents was that "an Irish nurse may secretly carry the infant to a priest, and have it baptized in the Catholic church, herself standing godmother." ${ }^{40}$ Thus, when no American girls were available, middle-class white women sought, at least, to hire Protestants. "Sarah and I ran out to 38 Carmine Street to see German girl, Protestant," wrote Caroline Dunstan in her diary on 24 January 1857. Routinely frustrated by the irresponsibility of Irish Catholic servants, Dunstan was eager to hire a new girl from the Reformed religion. Dunstan was not alone in this desire, however, for despite her haste, she arrived to find that the girl had already been "engaged, said 27 ladies had called before me." ${ }^{41}$ A more satisfied mistress reported, "I have a neat, active young girl as a servant, and consider myself very fortunate in having been able to procure one, who being a Protestant will attend our church and join us at family prayers." ${ }^{42}$

Non-white, non-Protestant servants were acutely aware of the disadvantages they faced on account of their religion and race. When Lucy Lee, the Yankee servant at the center of Catharine Maria Sedgwick's novel Live and Let Live lamented her unemployment, Biddy, a friendly Irishwoman and fellow domestic consoled her. "Och, child! Ye should not fret," reassured Biddy. "Ye'll be after soon finding a place. It is not with you as with them that an't born in their native land." 43 Sure enough, Lucy was hired the very same afternoon. Not only did white Protestant women find service jobs more easily, but also they were generally better paid. On 11 September 11 1856, Caroline Dunstan wrote that she had interviewed "a Protestant girl, but would not take less than 8 dollars." As Dunstan was only willing to offer wages of six dollars per month, she reconciled herself to "another, Roman [Catholic] ... engaged to come next day at 3." "44 Because 
Protestant servants could command such relatively high wages, a number of immigrant serving girls denied or misrepresented their Catholic heritage. ${ }^{45}$ This, in turn, inspired even more suspicion among potential employers like Dunstan, who_-still looking for a reliable servant in February 1857—complained that she had interviewed "five or six girls from Office, said they were Protestant, but no city references." "46 Because an Irish Catholic maid was generally presumed to be someone "disrespectful or insolent, or who persists in asserting a falsehood," her references were all-important. ${ }^{47}$

Despite the enthusiasm with which white mistresses hired white nativeborn American maids, the politically charged nature of their relationship usually made for an uneasy co-existence. Indeed, the very reasons why white Yankee women seemed like ideal domestics also served to undermine their relationships with the employing family. White maids, after all, could readily identify with their mistresses' racial and political condition, which, in turn, conflicted with the blackened and servile nature of the work they were expected to perform. This caused them to "command ... a little independence." 48 After 1840, with the system of helps a thing of the past, mistresses frequently complained that their Yankee maids were presumptuous and made demands that were unreasonable and inappropriate. Upon being told by her mistress that she "must not forget that in accepting a servant's place you accept a servant's limitations," one white maid abruptly quit her position and left service forever. ${ }^{49}$ White maids reportedly complained about their living conditions more often than non-whites and resented being unable to eat the same food that they served to their employers' tables. ${ }^{50}$ But it was not just the quality of the food that made mealtimes bitter for Yankee women; they also objected to dining alongside their non-white co-workers. The blackened conditions of service became especially obvious and objectionable to Yankee women when they were physically forced to share those conditions with non-whites. Louisa May Alcott wrote of one white housemaid who "thought her white skin gave her a right" to expect better accommodations than her employer's African American cook. ${ }^{51}$ Sleeping space was another contentious issue. In her famous Treatise on Domestic Economy, Catharine Beecher advised mistresses that they could not expect "American" girls to share a chamber-let alone a bed-with a "coarse and dirty foreigner." ${ }_{52}$ As the result of such tensions, many mistresses found that they could not maintain racially-mixed serving staffs. Yankee domestics, like the fictional Abigail in Sarah Josepha Hale's Keeping House and Housekeeping, often quit their positions when their mistresses brought a black servant into the household. Protesting the presence of Jethro, an African American waiter who had been retained to serve at a dinner party, Abigail promptly resigned, and told her mistress "I wouldn't live with a Negro. 'Birds of a feather may flock together'.",53 Explaining her difficulty in finding a new housemaid, one hiring mistress grumbled, "the black cook ha[s] been an insurmountable obstacle." ${ }^{54}$

White, native-born servants appeared disproportionately more often in 
domestic literature than they ever did in antebellum middle-class households. Storylines about Yankee servants generally fell into one of three patterns. In novels such as Susan Pike, Home and Little Women (in which the March family cook, Hannah, was a minor but essential character) white domestics served their employers faithfully, happily and without incident. But the domestic relationships portrayed in these stories are notable for their extreme sentimentality, their nostalgic tone and the ways in which the middle-class white family consciously endeavored to replicate the spirit and dynamic of the old system of helps. Anne Barcaly, the white mistress at the center of Catharine Maria Sedgwick's novel Home, even invokes the philosophy of an older generation when she notes, "Mother says there would be not half so much complaining of help, if the master and mistress had a religious sense of their duties to [servants] and took proper pains to promote their happiness." 55

A second narrative pattern traced the experiences of a privileged white woman who (through no fault of her own) encounters financial reverse. Because she knows that she is white, and therefore unlikely to be exploited or impugned by domestic labour, the "fallen possible lady" seeks work in service as a temporary measure to make ends meet. ${ }^{56}$ This employment sets the stage for a confrontation between the protagonist and her somehow maladroit mistress. Eventually, the white servant saves the day and is happily restored to her rightful social position, often through marriage to a respectable man. Sedgwick's Live and Let Live is one prominent example of this genre. The novel's heroine Lucy Lee enters service over the objections of her father, a down-and-out attorney who insists: "Never, never-all the talking in the world won't persuade me to degrade Lucy to a servant." ${ }^{57}$ But after several years in service, Lucy is able to fulfill the destiny prophesied by one of her employers, the charitable Mrs. Hyde, who had proclaimed, "no American girl's perspective is without a home and a good husband." ${ }^{58}$ A related plot follows the story of Christie Devon, the "poor gentlewoman" who is the protagonist of Louisa May Alcott's semi-autobiographical novel Work." Pledging that she is "not going to sit and wait for any man to give me independence, if I can earn it for myself," Christie Devon embarks on a series of short careers in various occupations, beginning with domestic service. ${ }^{60}$ The experiment in service is a failure, for, as the author explains: "There are many Christies, willing to work, yet unable to bear the contact with coarser natures which makes labour seem degrading." ${ }^{\prime 1}$ By the novel's end, however, Christie has married a middle-class Quaker man and is restored to a life of comfort.

The third fictional pattern is in many ways the most intriguing and reveals the most about how household relationships shaped middle-class white women's racial identities. In this schema, a white woman came to serve in a sympathetic household, but soon asserted her extreme, headstrong republicanism in a way that not only challenged her prescribed servile status, but also rivaled the authority of her mistress. Mrs. Hopkins, the white housekeeper hired by the Harley family in 
Sarah Josepha Hale's novel Keeping House and Housekeeping, created immediate problems for her employer. Arriving at the Harley home for her first day of work, Mrs. Hopkins conveyed an aura that "was masculine in the extreme; she looked competent to navigate a ship, to say nothing of managing a house." ${ }^{2}$ In this context, the apparent manliness of the housekeeper served to suggest that she would not be easily ordered about like a typical hireling. Moreover, the fact that she commanded a formal form of address (unlike most servants who were called by their first names, or even by a generic name selected by their employers, like "Bridget") illustrates that Mrs. Hopkins felt herself deserving of deference-and was reluctant to pay it. At once she informed her mistress "that her place was at the table with herself and husband; that if she [Harley] intended to make a servant of her, she would find out her mistake." ${ }^{\prime 3}$ But the Harleys do make such a mistake and nearly pay for it with the life of their young son before Mrs. Hopkins is sent away. The protagonist of a story published in 1855 was Fanny Fairhaven, "an American girl; came well recommended was honest, quick with her hands, a good cook, and understood housework generally." She went straight to work cleaning and organizing her employer's household, but such productivity did not last long. Her mistresses complained that "Fanny's fit of neatness and smartness soon passed away. Her fretfulness increased. Her room was too small and warm; the stairs were too narrow and steep." It is not long before "Fanny's dynasty" gives way, however, following her complaint that her accommodations were less comfortable than her employer's ("her room had but one window-mine had two"). The real problem with this servant - as readers might have predicted by her surname "Fairhaven" — was that she was simply too white to accept the conditions of service and so she too had to be dismissed. ${ }^{64}$

As the white servant asserted her own rights, these antebellum stories inevitably climaxed in a struggle with her mistress for control of the household. In most cases, like the stories of Mrs. Hopkins and Fanny Fairhaven, this battle was metaphorical. But in one noteworthy tale, a presumptuous white servant literally came to blows with her mistress in a pitched battle for domestic control. Intriguingly titled "A Common Experience," this short story traces the relationship between Helen Goodrich, a white middle-class woman (with another allegorical surname) and her Yankee servant, Mehitable Hilliard. Like the employers of Mrs. Hopkins and Fanny Fairhaven, Helen was initially relieved "to secure the services of a woman whom I had heard so much of and so well of, that I was anxious to get her. She was American." Soon, however, Helen realized that "not the kitchen only, but the whole house, and all its appurtenances, were brought under her [Mehitable's] strong control. I was no longer mistress ... She got the upper hand." The only way that Helen could regain authority was through physical confrontation, which came after a heated discussion one day when the servant refused to execute her mistress' planned dinner menu. Striking Mehitable's wrists with a kitchen utensil and trapping them against the table, Helen insisted, "Mehitable! I 
am mistress just now, and want soup, such as I described to you for dinner." As a result of this confrontation, Mehitable's "prestige, her ascendancy was crushed ... her spirits could not rally, and she came the next day and begged to be dismissed." Mehitable's Yankee replacement, Miss Aurelia, was similarly recalcitrant, leading Helen to attribute their presumptuous nature to their ethnic identification and upbringing. "There is no such thing as a servant in their vocabulary," she concluded. "The history, progress, genius and characteristics of the Yankee in effect forbid the use of the word ... They are willing to work; but must, in all respects, be treated as equals by their employers." And since equality between mistress and maid was no longer possible, the moral of the story was that white women ought not to be considered for blackened service positions. ${ }^{65}$

These fictional stories of white domestics who overstepped their authority were not intended to malign or condemn Yankee servants. Rather, their authors sought to explain that white women were neither politically nor racially suited for service and that any attempt to employ white women in this way would lead to a perversion both of republican ideals and of household order. White domestics' unfitness for blackened labour was implicitly expressed in the oftenrepeated complaint: "the first year she was an excellent servant; the second year she was a kind mistress; the third year she was an intolerable tyrant." This telling statement describes the evolution in political consciousness that was experienced by a white maid who spent too long in service. Though she was at first "an excellent servant" who worked to the benefit of the hiring household, the white domestic was improbably adopting a degraded and foreign status. According to the emerging racial ideology of the antebellum North, the true role of any white woman within the household was as the mistress, not the maid. Thus, as water finds its natural level, the Yankee servant began to take on the rights and responsibilities of her employer, imagining herself not as a servile dependent, but as "a kind mistress." However, because no one household could support two mistresses-and because the middle-class white employer could not acknowledge authority in her supposed subordinate-the white servant eventually abandoned her republican principles and attempted to seize authority as "an intolerant tyrant." Therefore, despite employers' general preference for hiring white domestics, such relationships often failed; not only did they violate the racial hierarchy of the antebellum North, but also through their potential to end in tyranny, they threatened the republican integrity of the household. As long as the domestic positions of mistress and maid were separated by a perceptible colour line, however, tyranny was banished from the home, and republican relations prevailed-much as they did within society at large.

The contemporaneous shifts in household labour from helps to servants, from Yankee to Irish, and from companion to drudge were, as Faye Dudden has argued, essentially coincidental. ${ }^{67}$ The effects of industrialization on household service shared no causal relationship either with the pattern of Irish immigration 
or with Irish women's emerging economic needs. However, the related timing of these shifts led white middle-class mistresses to see them as connected-especially since the forces combined to drive Yankee women out of service. Moreover, this perceived connection confirmed their stereotypes of the Irish and African Americans as inadequate employees; as moral, intellectual and political inferiors; and as the source of the "servant problem" infecting the upper echelons of Northern urban society. By blaming their new, non-white servants, rather than larger economic changes as the reason for the decline of the system of helps and for the intrusion of commercial transactions and unrepublican relations into the home, middle-class white women were, in fact, transferring their anxieties about the appearance of republicanism and the encroachment of commerciality in the household. The only way that white women could justify such new-fangled relationships was to view them with an overlay of race difference. The newly defined whiteness of the mistress and the blackness of the maid created a logic of race where no other explanatory logic existed. A middle-class white woman by this rationale, could appropriately pay wages to and expect deference from a servant, without seeming either unwomanly or unrepublican. Of course, by the same principle, in the mistress' eyes, no servant could be womanly, middle-class, republican or white. In the US in the twenty-first century, this stigma continues to afflict domestic labour.

\section{Notes}

1. Faye Dudden, Serving Women: Household Service in Nineteenth-Century America (Middletown, CT: Wesleyan University Press, 1983); Carol Lasser, "The Domestic Balance of Power: Relations between Mistress and Maid in Nineteenth-Century New England," Labor History 28 (Winter 1987).

2. William Alcott, The Young Wife (Boston: George W. Light, 1837), 166.

3. Lydia Maria Child, The Mother's Book (New York: Arno Press, 1972), 117.

4. Joseph Lyman and Laura Lyman, The Philosophy of Housekeeping (Hartford: Goodwin and Betts, 1867), 500.

5. The Housekeeper's Book, By a Lady (Somersworth, NH: New Hampshire Publishing Company, 1972), 40.

6. Six Hundred Dollars a Year: A Wife's Effort at Low Living Under High Prices (Boston: Ticknor and Fields, 1867), 6.

7. For a nuanced account of white New Englanders' relationship to their own history of slaveholding, see Joanne Pope Melish, Disowning Slavery: Gradual Emancipation and "Race" in New England, 1780-1860 (Ithaca, NY: Cornell University Press, 1998).

8. Christine Stansell calculates that by 1855 , only 4 percent of the domestic workers in New York City were native-born white American women, while Irish women comprised 74 percent of the total. An additional 14 percent were Germans, who worked predominantly in German-speaking households. Most of the remainder were African Americans. Christine Stansell, City of Women: Sex and Class in New York, 1790-1860 (Urbana, IL: University of Illinois Press, 1982), 156. For more on Irish working women in America, see Hasia Diner, 
Erin's Daughters in America: Irish Immigrant Women in the Nineteenth Century (Baltimore: Johns Hopkins University Press, 1983), and Margaret E. Lynch-Brennan, "Ubiquitous Biddy: Irish Immigrant Women in Domestic Service in America" (Ph.D. diss., SUNY Albany, 2003).

9. David Roediger, The Wages of Whiteness: Race and the Making of the American Working Class (New York: Verso, 1991); Noel Ignatiev, How the Irish Became White (New York: Routledge, 1995); Matthew Frye Jacobson, Whiteness of a Different Color: European Immigrants and the Alchemy of Race (Cambridge, MA: Harvard University Press, 1998).

10. Jeanne Boydston, Home and Work: Housework, Wages and the Ideology of Labor in the Early Republic (New York: Oxford University Press, 1990), 144, 158.

11. Caroline Gilman, Recollections of a Housekeeper (New York: Harper and Brothers, 1834), 66, 92. For more on the significance of this terminology, see Roediger, 47-49.

12. Catharine Maria Sedgwick, Home (Boston: James Monroe and Company, 1835), 8, 72.

13. Catharine Maria Sedgwick, Preface to Live and Let Live, or Domestic Service Illustrated (New York: Harper and Brothers, 1837), v.

14. Eliza Follen, Sketches of Married Life (Boston: Hilliard, Gray and Company, 1838), 221.

15. Harriet Spofford, The Servant Girl Question (Boston: Houghton Mifflin and Co., 1881), 13.

16. Fanny Fern, Ruth Hall (New Brunswick, NJ: Rutgers University Press, 1990), 52. Despite Biddy's pronouncement, Ruth does manage, though Fern is also careful to explain that Ruth's aptitude for domestic labour was the result of her Yankee ingenuity and spirit of independence.

17. Sedgwick, Live and Let Live, 70-71.

18. Emma Willard, "Via Media: A Peaceful Settlement of the Slavery Question" (Washington: C.H. Anderson, 1862), 3.

19. Lydia Maria Child, Letters from New-York, Second Series (New York: C.S. Francis and Co., 1845), 104.

20. James Henry Hammond, speech to United States Senate, 4 March 1858.

21. Roediger, 47.

22. Spofford, 6 .

23. Lucy Maynard Salmon, Domestic Service, 2nd ed. (New York: The MacMillan Company, 1901), 71-72.

24. Louisa May Alcott, Work, A Story of Experience (New York: Penguin Books, 1972), 17, 30.

25. Frederick Douglass, Narrative of the Life of Frederick Douglass, An American Slave (New York: Signet, 1968), 117.

26. Sarah Josepha Hale, Keeping House and Housekeeping: A Story of Domestic Life (New York: Harper and Bros., 1845), 65.

27. Eliza Leslie, Miss Leslie's Behaviour Book, A Guide and Manual for Ladies (New York: Arno Press, 1972), 307.

28. Cited in Elizabeth L. O'Leary, At Beck and Call: The Representation of Domestic Servants in Nineteenth-Century American Painting (Washington: Smithsonian Institution Press, 1996), 59.

29. Leslie, 309.

30. For more on the political and racial connotations of the word "boss" in its antebellum context, see Roediger, 50-54.

31. While the recent historiographies of race and whiteness have said nothing about the construction of white racial identity among middle-class Northern urban white women, they have convincingly established the fact that antebellum Irish immigrants to the US were-despite their blue eyes and fair complexions-categorized as non-white. Scholars, 
most prominently David Roediger and Noel Ignatiev, have demonstrated that the willingness of Irish men to perform degraded labour imperiled their racial status in the republic and carved a vast chasm separating them from their employers and other people of European descent. To date, no parallel study of the racial identity of Irish women in America has been undertaken, but it seems quite clear that the Irish women who worked in service faced a struggle against white prejudice that was similar to, but even more complex than that of Irish men. For unlike their fathers and brothers, female Irish immigrants to the US entered an occupation that was already suspected of being unrepublican and was undergoing fundamental changes in ideology, composition and nature. In combination, these factors provided for the denigration of domestic service as a trade and for the blackening of all women who entered it in the decades after 1840. (Roediger, 133-163; Ignatiev, 34-61 and throughout.)

32. Willard, 3.

33. Helen Campbell, "Speak-Out on Domestic Service," reprinted in Root of Bitterness: Documents in the Social History of American Women, Nancy F. Cott ed. (New York: E.P. Dutton and Co., Inc., 1971), 322.

34. Campbell, 326.

35. Sedgwick, Live and Let Live, 36. Lucy's resolve here foreshadows the advice given to servants by Sarah Josepha Hale two years later. In Susan Pike, a novel written for and about domestics, Hale counsels: "Do not work merely for money, but seek to gain the affections of your employers, and thus enjoy the happiness which this relation affords." Sarah Josepha Hale, Susan Pike; or a Few Years of Domestic Service. A Tale (New York: Chas. S. Francis, 1839), 13.

36. Roediger, 45.

37. Sedgwick, Live and Let Live, 39-40.

38. Sedgwick, Live and Let Live, 33.

39. Sedgwick, Live and Let Live, footnote on 114.

40. Leslie, 290-291.

41. Caroline Dunstan Diary, 24 January 1857. Caroline A. Dunstan Diaries, New York Public Library. A week later, on 30 January, Dunstan reported that she had been "off to Attorney and Ridge streets for a Protestant widow, too late."

42. Madeline Leslie, The First and Second Marriages; or, the Courtesies of Wedded Life (Boston: Shepard, Clark and Co., 1856), 110.

43. Sedgwick, Live and Let Live, 33.

44. Dunstan Diary, 22 September 1856.

45. Dudden, 69.

46. Dunstan Diary, 6 February 1857.

47. E. Leslie, 105.

48. Hale, Keeping House and Housekeeping, 11.

49. Campbell, 325.

50. Plain Talk and Friendly Advice to Domestics; With Counsel on Home Matters (Boston: Phillips, Sampson and Company, 1855,) 38.

51. L.M. Alcott, Work, 22.

52. Catharine Beecher, A Treatise on Domestic Economy (Boston: Marsh, Capen, Lyon and Webb, 1841), 199.

53. Hale, Keeping House and Housekeeping, 72-73. For a sampling of similar tales, see L.M. Alcott, Work, 19; Hale, Susan Pike, 19. 
54. L.M. Alcott, Work, 17.

55. Sedgwick, Home, 7-8.

56. "A fallen possible lady" is how Catharine Maria Sedgwick describes the white female servant at the center of her novel Live and Let Live. Sedgwick, Live and Let Live, 24.

57. Sedgwick, Live and Let Live, 15.

58. Sedgwick, Live and Let Live, 198.

59. L.M. Alcott, Work, 117.

60. L.M. Alcott, Work, 9.

61. L.M. Alcott, Work, 117.

62. Hale, Keeping House and Housekeeping, 45.

63. Hale, Keeping House and Housekeeping, 49.

64. Story told in Plain Talk, 27-31.

65. "A Common Experience," Plain Talk, 89-109. (Emphasis appears in original.)

66. Catharine Beecher, Miss Beecher's Housekeeper and Healthkeeper (New York: Harper and Brothers, Publishers, 1873), 435. The author of Trials and Confessions of an American Housekeeper warned the employers of white servants that they could expect that "your servant soon becomes your mistress — or soon at least, makes bold efforts to assume that position." Trials and Confessions of an American Housekeeper (Philadelphia: Lippincott, Grambo and Co, 1854), 110.

67. Dudden, 60. 